\title{
Gender and Politics
}

Series Editors: Johanna Kantola, Senior Lecturer in Gender Studies, University of Helsinki, Finland; and Sarah Childs, Professor of Politics and Gender, University of Bristol, UK

This series publishes leading monographs and edited collections from scholars working in the disciplinary areas of politics, international relations, and public policy with specific reference to questions of gender. It showcases cutting-edge research in Gender and Politics, publishing topical and innovative approaches to gender politics from new authors and well-known academics as well as practitioners working on related issues.

The series covers gendered engagement with mainstream political science issues, such as political systems and policymaking, representation and participation, citizenship and identity, equality, and women's movements; gender and international relations, including feminist approaches to international institutions, political economy, and global politics; and interdisciplinary and emergent areas of study, such as masculinities studies, gender and multiculturalism, and intersectionality.

\section{Series Advisory Board:}

Louise Chappell, University of New South Wales, Australia Joni Lovenduksi, Birkbeck College, University of London, UK Amy Mazur, Washington State University, USA Judith Squires, University of Bristol, UK Jacqui True, Monash University, Australia

Mieke Verloo, Radboud University Nijmegen, the Netherlands Laurel Weldon, Purdue University, USA

Titles include:

Gabriele Abels and Joyce Marie Mushaben (editors)

GENDERING THE EUROPEAN UNION

New Approaches to Old Democratic Deficits

Phillip Ayoub and David Paternotte

LGBT ACTIVISM AND THE MAKING OF EUROPE

A Rainbow Europe?

Elin Bjarnegård

GENDER, INFORMAL INSTITUTIONS AND POLITICAL RECRUITMENT

Explaining Male Dominance in Parliamentary Representation

Elgin Brunner

FOREIGN SECURITY POLICY, GENDER, AND US MILITARY IDENTITY

María Bustelo, Lucy Ferguson, and Maxime Forest (editors)

THE POLITICS OF FEMINIST KNOWLEDGE TRANSFER

Gender Training and Gender Expertise

Sarah Childs and Paul Webb

SEX, GENDER AND THE CONSERVATIVE PARTY

From Iron Lady to Kitten Heels 
Jonathan Dean

RETHINKING CONTEMPORARY FEMINIST POLITICS

Meryl Kenny

GENDER AND POLITICAL RECRUITMENT

Theorising Institutional Change

Andrea Krizsan, Hege Skjeie, and Judith Squires (editors)

INSTITUTIONALIZING INTERSECTIONALITY

The Changing Nature of European Equality Regimes

Mona Lena Krook and Fiona Mackay (editors)

GENDER, POLITICS AND INSTITUTIONS

Towards a Feminist Institutionalism

Emanuela Lombardo and Maxime Forest (editors)

THE EUROPEANIZATION OF GENDER EQUALITY POLICIES

A Discursive-Sociological Approach

Birte Siim and Monika Mokre (editors)

NEGOTIATING GENDER AND DIVERSITY IN AN EMERGENT EUROPEAN PUBLIC SPHERE

Anna van der Vleuten, Anouka van Eerdewijk, and Conny Roggeband (editors)

GENDER EQUALITY NORMS IN REGIONAL GOVERNANCE

Transnational Dynamics in Europe, South America and Southern Africa

Polly Wilding

NEGOTIATING BOUNDARIES

Gender, Violence and Transformation in Brazil

Gender and Politics Series

Series Standing Order ISBNs 978-0-230-23917-3 (hardback) and

978-0-230-23918-0 (paperback)

(outside North America only)

You can receive future titles in this series as they are published by placing a standing order. Please contact your bookseller or, in case of difficulty, write to us at the address below with your name and address, the title of the series and the ISBN quoted above.

Customer Services Department, Macmillan Distribution Ltd, Houndmills, Basingstoke, Hampshire RG21 6XS, England 


\section{The Politics of Feminist Knowledge Transfer}

\section{Gender Training and Gender Expertise}

Edited by

María Bustelo

Associate Professor, Departamento de Ciencia Política de la Administración II, Universidad Complutense de Madrid, Spain

Lucy Ferguson

Associate Researcher, Unidad de Género, Instituto Complutense de Estudios Internacionales, Universidad Complutense de Madrid, Spain

Maxime Forest

Senior Researcher and Lecturer, Sciences Po Paris, OFCE, CEVIPOF, France 


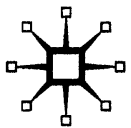

Selection, introduction, conclusion, and editorial matter (c) María Bustelo, Lucy Ferguson, and Maxime Forest 2016

Foreword (C Myra Marx Ferree and Mieke Verloo 2016

Individual chapters (O Respective authors 2016

All rights reserved. No reproduction, copy or transmission of this publication may be made without written permission.

No portion of this publication may be reproduced, copied or transmitted save with written permission or in accordance with the provisions of the Copyright, Designs and Patents Act 1988, or under the terms of any licence permitting limited copying issued by the Copyright Licensing Agency, Saffron House, 6-10 Kirby Street, London EC1N 8TS.

Any person who does any unauthorized act in relation to this publication may be liable to criminal prosecution and civil claims for damages.

The authors have asserted their rights to be identified as the authors of this work in accordance with the Copyright, Designs and Patents Act 1988.

First published 2016 by

PALGRAVE MACMILLAN

Palgrave Macmillan in the UK is an imprint of Macmillan Publishers Limited, registered in England, company number 785998, of Houndmills, Basingstoke, Hampshire RG21 6XS.

Palgrave Macmillan in the US is a division of St Martin's Press LLC, 175 Fifth Avenue, New York, NY 10010.

Palgrave Macmillan is the global academic imprint of the above companies and has companies and representatives throughout the world.

Palgrave ${ }^{\circledR}$ and Macmillan ${ }^{\circledR}$ are registered trademarks in the United States, the United Kingdom, Europe and other countries.

ISBN 978-1-137-48684-4 ISBN 978-1-137-48685-1 (eBook)

DOI 10.1057/978-1-137-48685-1

This book is printed on paper suitable for recycling and made from fully managed and sustained forest sources. Logging, pulping and manufacturing processes are expected to conform to the environmental regulations of the country of origin.

A catalogue record for this book is available from the British Library.

Library of Congress Cataloging-in-Publication Data

Names: Bustelo, Marla, editor. | Ferguson, Lucy, 1978- editor of compilation. | Forest, Maxime, 1976- editor of compilation.

Title: The politics of feminist knowledge transfer:gender training and gender expertise / edited by Marla Bustelo, Lucy Ferguson, Maxime Forest.

Description: New York, NY : Palgrave Macmillan, 2016. | Series: Gender and politics | Includes bibliographical references and index.

Identifiers: LCCN 2015026440 | ISBN 9781137486844 (hardback)

Subjects: LCSH: Feminist theory. | Knowledge, Theory of. | Sex role. | Women's rights. | Women in development. | BISAC: POLITICAL SCIENCE / History \& Theory. | SOCIAL SCIENCE / Feminism \& Feminist Theory. I SOCIAL SCIENCE / Gender Studies.

Classification: LCC HQ1190 .P655 2016 | DDC 305.4201-dc23

LC record available at http://lccn.loc.gov/2015026440 
We would like to dedicate this book to our fellow community of practitioners and researchers, united in our ongoing search for feminist transformation. 


\section{Contents}

List of Figures and Tables $\quad$ ix

Foreword by Myra Marx Ferree and Mieke Verloo $\quad \mathbf{x}$

Acknowledgements $\quad$ xix

Preface $\quad$ xx

Notes on Contributors $\quad$ xxiv

Introduction 1

María Bustelo, Lucy Ferguson, and Maxime Forest

Part I Key Issues in Feminist Knowledge Transfer

1 How to Wield Feminist Power 25 Elisabeth Prügl

2 Resistance in Gender Training and Mainstreaming Processes 43 Emanuela Lombardo and Lut Mergaert

3 Gender Expertise and the Private Sector: Navigating the Privatization of Gender Equality Funding Lucy Ferguson and Daniela Moreno Alarcón

4 The Smothering of Feminist Knowledge: Gender Mainstreaming Articulated through Neoliberal Governmentalities

Tine Davids and Anouka van Eerdewijk

\section{Part II Critical Case Studies of Feminist Knowledge} Transfer

5 Windows of Opportunity, Trojan Horses, and Waves of Women on the Move: De-colonizing the Circulation of Feminist Knowledges through Metaphors?

Rahel Kunz

6 Gender Training as a Tool for Transformative Gender Mainstreaming: Evidence from Sweden Anne-Charlott Callerstig 
viii Contents

7 Between Knowledge and Power: Triggering Structural Change for Gender Equality from Inside in Higher Education Institutions

Viviane Albenga

Conclusions

María Bustelo, Lucy Ferguson, and Maxime Forest

Appendix: Madrid Declaration on Advancing Gender+ Training in Theory and Practice

Index 


\section{Figures and Tables}

Figures

3.1 Thematic focus of private sector initiatives on gender equality 65

6.1 Theoretical learning model 123

6.2 Dissonance theory 123

Tables

2.1 Forms of resistance by trainees related to examples and types 53

6.1 Two perspectives on change 


\section{Foreword}

\section{Gender Inequality and Institutional Knowledge: The Politics of Knowledge Transfer}

The chapters in this book offer a rich variety of critical perspectives on the "knowledge work" being undertaken today to increase awareness of gender inequality; help understand how it operates as a system; and intervene in specific ways to transform organizations where gender is embedded and reproduced. Encouraged by mandates from the UN and EU to "mainstream gender" into policy processes, gender equality advocates around the world have taken up the challenge to help train policymakers. Training policymakers is intended to help them recognize how gender operates systematically in their areas of competence and to be able to respond with new policy initiatives designed to shift their organizations' routines towards producing equality rather than reproducing inequalities.

Mainstreaming gender, however, is never just about educating willing learners. Gender inequality is actively supported by the ongoing activities, conscious and unconscious, of a wide range of actors, some of whom benefit from current configurations of gender relations. Thus, gender mainstreaming, gender training, and feminist knowledge transfer inevitably engage in a "gendered politics" of knowledge. By politics, we mean here not only that there are different ideas about what knowledge is, or which knowledge is considered more real or valuable than others. We also mean that power is dynamically at work in the processes of knowledge construction and knowledge diffusion. Gender-based power and gender-based knowledge are embedded in ideological, material, and positional differences, all of which are deeply rooted in historical legacies that are context dependent.

The processes of feminist knowledge transfer that facilitate awareness and understanding of the dynamics and consequences of gender inequality thus occur in settings where participants have real differences in their interests. Alongside the participants who are eager and willing to learn, there always are participants who are sceptical and reluctant, and participants who actively oppose any challenge to their understanding of the gender unequal reality as being "normal", "just", or "inevitable". Working to transfer feminist knowledge for the purpose of increasing equality therefore also means challenging the tenets of knowledge whose purpose is to secure and legitimate gender inequality. This cannot be done without also working to change the relations of power that create the facts on the ground that "everybody knows". 
If we want to improve gender mainstreaming and gender training, it has emerged as necessary to have a solid perspective on how to deal with the resistances and rejections inherent in the inequality-supporting politics of knowledge. Recognizing that this is not just the training of somehow unknowing or unskilled learners, but rather engaging with others whose "truth commitments" are structured around different premises, can lead to more effective change strategies. This is true if different interests are organized around feminist and anti-feminist claims about inequality. However, it can also reflect a struggle between those whose claim to truth is based on their experiences and those whose claim to truth is grounded in a set of theoretical claims about how the world works, only some of which can be empirically tested in a given situation.

In this Foreword, we draw from scholarly insights about gender mainstreaming and the discursive dynamics of gender equality, combining this with our experiences as academics engaging in teaching and learning about gender, to present some ideas about the politics of knowledge transfer. We find the book helpful in moving the discussion of knowledge transfer away from views of learners as passive, disempowered, or ignorant, and instead in questioning the hierarchy of knowledge sometimes imbedded in the term "training". We applaud the book's explicit recognition that what is going on under the name of "training" actually involves a more contested politics, particularly since this engagement is so poorly captured in the typical evaluations of training itself as being "successful" or "unsuccessful" in a particular organizational context.

As members of the US-EU knowledge-creating project TARGET (Transatlantic Applied Research in Gender Equity Training), we participated in many workshops in which trainers and researchers exchanged perspectives based on their experiences with the goals of increasing knowledge about gender in the policymaking world. The grounding of the trainers' knowledge in work with commissioners of gender equality interventions, as well as with the recipients of such gender training programmes, provided us with a level of critical insight into the knowledge transfer process that we, as academically based researchers, would not otherwise have had. The OPERA subproject of the QUING initiative further emphasized the needs that trainers have for a broader and deeper view of the field as a whole. It also encouraged us as researchers to see what we could contribute to the mutual learning process surrounding feminist knowledge transfer.

Because QUING (Quality in Gender+ Equality Policies, see www.quing.eu) in particular was oriented to thinking more intersectionally about multiple inequalities, the questions of knowledge transfer that it raised also went beyond a uni-dimensional process of transferring gender knowledge from the "expert" to the "trainee". Although gender maintains a central position in "gender+" analysis, the intersectional approach that it advocates is itself an extension of feminist knowledge that arose out of the practical 
experiences of trying to create "gender equality" in conditions of racialized inequalities. Kimberlé Crenshaw's $(1989,1991)$ introduction of the term "intersectionality" arose from her experience as an African American woman lawyer who was working on applications of US laws concerning employment discrimination and violence against women to women of colour. The erasure of their situation from the eyes of the law was a practice-based form of knowledge construction that today informs feminist theory across a wide variety of fields.

Both TARGET and QUING provided concrete situations for mutual listening to occur. Practitioners working regularly in organizations mandated to include a "consideration of gender" in their ordinary processes of decisionmaking faced very different challenges than those of us whose jobs were defined as reflecting on, and theorizing about, the work of organizational change. Rather than coming into these workshops thinking that either practitioners or social scientists were the possessors of "truth" that needed to be taught to the other, we encountered each other with a sense of curiosity about what the other knew and how they came to know this. By establishing sites for mutual learning, TARGET and QUING challenged the common assumption that knowledge transfer is always from academic to practitioner, from theory to application, from the general to the specific. The specificity of each practitioner's skills and experience created standpoints from which particular knowledge could be constructed and from which empirical generalizations could be made. Rather than "theory" being constructed and applied to these practices, the practitioners offered their own theories to academic researchers to investigate further.

What made this mutual learning possible? We suggest that there are several important preconditions for engaging in a shared process of knowledge construction that were met in these projects and could be more often attempted. First, the participants came together with a common commitment to making feminist change happen, rather than positioning themselves as either teachers or learners. On the one hand, the idea of a "workshop" potentially challenges the hierarchies built into academia and how it treats students and research subjects as subordinate to the authority of researchers. On the other hand, it challenges the hierarchy built into the practices of gender training, which give authority to "gender experts" to frame the experiences of the members of the organization being trained. As several of the chapters of this book explain, the competing claims to epistemological authority by feminist academics and practice-based gender experts can easily become a battleground for the power to define knowledge and to rank methodologies. This risks allowing their common interests in equality politics to fade from view.

The absence of financial incentives for controlling the definitions of expertise in these projects was another important precondition for working together in a less hierarchical way. Because there was no contract to be 
won or research findings to be written up, at least in the short term, all participants could be persuaded that their own interest lay in the common endeavour of understanding how gender knowledge was being produced and (re)distributed rather than deciding who knows "best". The commodification of knowledge, by contrast - whether marketed by means of consultancies, expert reports, training contracts, research grants, or peer-reviewed books and articles - is a condition encouraging knowledge producers to claim ownership ("intellectual property rights") and fight for returns on their investments.

In capitalist systems, it may often be impossible to assume a financially disinterested stance towards knowledge as a good in its own right. Nevertheless, there still may be compelling alternative forms of reward in shared recognition of contributions to political and interpersonal goals. Taking financially costly stands on principle, or for the sake of peer approval, for example, is a common feature of shared-value networks that discriminate, like the "old boys" who affirm their group membership by acts of exclusion that may cost their organizations talent or social respect. It may also be common among those that contest discrimination, as transnational feminist advocacy groups and feminist trainers do. Nonetheless, the typical gap in interpersonal connections between "academic" and "activist" researchers may contribute towards mutual suspicion rather than perceptions of shared purpose. For example, each group of participants may impute merely instrumental motives for contact and cooperation to the other group. Certainly, during the TARGET project, we always had to deal with anxiety on both sides about who was "using" whom and who was "being used".

A third issue that arose in attempting to "meet in the middle" of the academic-activist gap was the problem of languages and translation. Although these workshops were always multi-national, it is not language in a national sense that posed a significant barrier. For better or worse, the dominance of English was normal. Instead, the academic-activist language gap about gender equality measures and organizational politics manifested as differences in what could easily be spoken about and what produced misunderstandings. The "commissioners" of research, for example, loomed large on the horizon of practitioners, whose work conditions and even livelihoods depended on them. By contrast, these commissioners were less obviously relevant to academic researchers, who looked to the implementation of a law or policy about mainstreaming as a more abstract and disembodied process. To speak of the "design" of an intervention, therefore, meant to practitioners a process entailing the power of commissioners to define goals, allocate resources, and demand results in a specified (and often unrealistic) timeframe. To academics, it meant the way that the practitioners responded to the charge of doing mainstreaming work - that is, the skills they developed, the tools they used, and the pedagogic rationales they offered for their approach. 
Another language trap in addition to "design" was the very nature of "gender inequality" as the target of transformational processes. As Verloo et al. $(2007,2011)$ have found in their Critical Frame Analyses of gender policy documents in the EU 27, "gender" is often thinned out into meaning only women. That is, policy speaks about what women do, and what happens to women in an organization, rather than addressing the ways that gender is about a relationship in which both men and women have positions and act on that basis. Is gender equality in an organization achievable by changing discriminatory attitudes that are interfering with what the organization was designed to do, or was producing gender inequality part of its basic function? Thinking about gender relationally, rather than as a synonym for women in organizations designed around men, raises different questions about what kinds of organizational features are "inequality-producing". For example, gender relations would need to be seen as part of how organizations relate to each other, not just how managers relate to the female- and male-bodied individuals they employ or serve.

The broader the questions, the more difficult the answers become. If "gender equality" could be produced within one ministry or one corporation without thereby upsetting the complex ordering of gender across other organizations and institutions, what does that imply about the social importance of that one ministry or corporation? What would "gender equality" mean if it were confined to one institutional setting, since the very complexity of gender relations makes every element intersect in multiple institutions? Implementing equal pay in a single organization still triggers changes in workplaces, families, state pension systems, and insurance markets, for example.

Another linguistic struggle arises with regard to understanding "diversity". Especially in the United States today, the word "diverse" is applied to describe populations that are actually mostly or entirely "persons of colour". Thus recruiting "diverse" students does not actually mean what it seems to say, but focuses attention on ethnic minorities who will bring their "diversity" into an organization by their very bodies, often without challenging how the organization defines itself already in terms of its "whiteness". In academic feminist discourse, "intersectionality" often serves a similar function of bringing in "the other", while obscuring the norms already embedded in social relations organized around heterosexism, national-religious loyalties, age, and able-bodiedness.

When intersectionality is thinned into merely examining women with non-normative positions who "bring in diversity", a supposedly intersectional analysis is not really going to be about "gender+" relations, but merely about "women-who-are-also" disadvantaged in multiple ways. Thin versions of diversity and intersectionality are more readily fed into existing systems. They underline the very "normality" of the unmarked that they were imagined as undermining and allow the marking of the "other" women 
or men to proceed unchecked. Treating diversity and intersectionality as if they were categories, rather than processes (Ferree, 2009), is often criticized by practitioners as well as academics. While we have often seen a thinning (or "smothering"), of the critique that the concepts of diversity and intersectionality offer, we are also encouraged to see an energetic debate about what these words mean, and what they actually do, in specific contexts. Our TARGET workshops convinced us that both academic and activist communities are internally heterogeneous in the ways they work to make their gender politics "diverse" and "intersectional".

This book not only captures some of the insights collectively constructed in the OPERA and TARGET workshops but invites reflection on the challenges for all feminists interested in advancing social justice in the world. If our purpose as feminists is not just to understand the world, but also to transform it, we require self-critical examination of our practices both within and outside of academia. By identifying valuable steps or dangerous missteps on the road to justice, self-evaluations of the processes by which we adopt specific goals, strategies, and tactics in various settings and with what resistances can be very fruitful types of analysis.

Moreover, consideration of the effects which these choices have on us is part of the reflexivity demanded by feminist models of truth-seeking. Taking ourselves seriously as situated change agents is not the same as expressing guilt about our social locations of privilege and disadvantage. In fact, it is unrealistic to demand that we be most aware of that which we are most likely to be overlooking, that is our own situated perspectives. Awareness of the partial and temporary nature of what we know is a realistic expectation that should spur efforts to listen respectfully, and even appreciatively, to those whose position is differently constituted. But at the same time, awareness of all knowledge as situationally conditioned and politically contested should also give us a more realistic view of the struggles that we encounter in the classroom, the research project, the training commission, or any other setting where differences are present and should be allowed to have a voice.

The authors in this valuable book come to their common project of understanding the politics of feminist knowledge transfer from positions that are identifiably different. Their very specificity of perspective is part of what informs their analysis and makes it so generally useful. While less than half of the contributors were part of the TARGET or OPERA projects directly, they have all been moving back and forth between trying to bring a gender+ analysis into use in policymaking and trying to analyse reflexively what such application efforts demand and produce. Perhaps not surprisingly, there are common themes of hope and disappointment mingled in their reflections on practice. But there are also differences in how much optimism they seem to have for the longer term project of provoking change in gender relations through feminist knowledge transfer and how critical they have become of aspects of this strategy. 
As already noted, one such important position shaping perceptions of possible, effective, and desirable courses of action is the academic/activist divide. A feminist politics of intersectionality demands some attention to how academics and activists relate to each other, not merely through the lens of difference but in a relationship of inequality. Professional status and employment security are significant resources in the struggle over whose knowledge is to be valued. Both status and security are unevenly distributed between academic and practitioner positions, without being uniformly high on one side and low on the other. Heterogeneity within each type of work, as well as between them, became apparent in the TARGET workshops. Along with this, a much more self-critical understanding of what makes an "ideal" trainer or researcher came to the fore.

On the one hand, each trainer or researcher is specific as to their particular discipline or type of intervention work and commands a variety of skills and insights. On the other hand, the inequality of position between academic and activist sets up certain types of locations of privilege for one or the other. To the extent that academic researchers enjoy the privileges of status and security, and not all do, they can afford a "longer view". Thus, they set their sights on more fundamental transformations ("radical changes") than practitioners in most situations, who tend towards categorizing more achievable "reforms". Without the luxury of being radical that longer term imagination offers, and needing to get up every morning and return to fight the good fight, practitioners may sell short, specific strategies that look "unrealistic" in the shorter time frame in which they operate. But to the extent that activists are engaged in actually having to use the limited power they have in a practical setting, they can see their allies more realistically and be more accurate diagnosticians of the resistances they face. Academics can idealize common interests abstractly, while practitioners will take their help where they find it. In sum, we come from our workshop experience sceptical about academics who think that practitioners don't "do theory" or "have vision". Instead, we have come to recognize that what is being imagined as relevant reflects quite different, but equally important, socially constructed needs for knowledge of particular kinds.

In fact, the reality that gender researchers and gender trainers face is one in which multiple discourses about gender are already circulating with different kinds of authority attached to their various truth claims. In addition to the important positionality to be recognized between academics and activists, we urge attention to differences that depend on positions in the wider world system of inequalities. That is, it is vital to recognize the gaps among knowledges produced in the Global South and North; in languages shared by large communities of native speakers, such as English, Spanish, or Chinese, and those expressed in the languages that few understand, such as Finnish, Turkish, or Korean; in the media of intellectuals, such as academic books and journals, as opposed to the media of mass communication, such 
as radio, TV, or films, or the media of the politically engaged, such as newspapers, blogs, and formal organizational training. This book only begins a conversation about how gender knowledge gets transferred within the context of bureaucratic organizations that choose to engage deliberately in this process. Nevertheless, the authors also do a wonderful job of making clear that this is never the only kind of gender knowledge transfer going on.

Additionally, the authors point to the great question of what kind of authority "gender training" is actually appealing to when it is introduced into an organization. Surely in the training process itself, it is sometimes "science", sometimes "law", and sometimes "managerial power" that provide authority backing the trainers' claims to impart knowledge and challenge existing beliefs among participants. But how do the counter-claims of the resistant participants receive their authority? Is it in the existing practices of the organization ("but we've always done it this way"), or in experience with a variety of gender-inequality-producing institutions ("but women are just not as competent/motivated/etc."), or in the managerial-technocratic logic of the bureaucracy itself ("but that has nothing to do with our main goal"). Engaging effectively with such varieties of knowledge claims demands a practical theory of gender transformation.

Practical theory is what this book offers in abundance, presenting both general visions and individual cases that illuminate the situations where gender equality advocates are actually struggling to turn out some version of a new, more gender-just reality. Because these struggles are concrete and sitespecific, even the general claims in the first section are tied to the kinds of support and resistance that become visible in actual struggles to frame problems and change interconnected systems. All of the authors in this section are not merely critics of what others have done, but are engaged in imagining the undertaking of the best possible feminist transformation work. They offer concrete suggestions about ethical principles in the abstract sense, but they also provide examples of how places to meet among themselves, as well as strategies to hear from the grassroots level, can function to resist the power exercised by donors over the work being done. Their pragmatic realism suggests that truth is known at different scales, as well as from different social locations.

As a guide for thinking about how feminist knowledge can circulate, the model this book offers is less one of orderly "transfer", as from a bank of accumulated knowledge, and more like a global storm than even the "waves in motion" metaphor suggests. In this storm, there are many forms of action - wind, waves, tectonic shifts - that are stirring things up and creating both positive and negative feedback into each other's effects, so that it is hard to tell what the shape of the world will ultimately be. The storm is not local but it is felt locally, and it is not directed, even if at different times different actors think that they have everything under control. But through the power of the storm, even that which has been seen as immovable can 
be shifted and new features of the landscape emerge. Gender equality is one such feature that feminist knowledge practices are making visible, even if as a still distant place on the horizon.

\section{Myra Marx Ferree and Mieke Verloo}

\section{References}

Crenshaw, Kimberlé (1989) "Demarginalizing the Intersection of Race and Sex: A Black Feminist Critique of Antidiscrimination Doctrine, Feminist Theory and Antiracist Politics", The University of Chicago Legal Forum, 140, 139-167.

(1991) "Mapping the Margins: Intersectionality, Identity Politics, and Violence against Women of Color", Stanford Law Review, 43(6), 1241-1299.

Ferree, Myra Marx (2009) "Inequality, Intersectionality and the Politics of Discourse: Framing Feminist Alliances", in Emanuela Lombardo, Petra Meier, and Mieke Verloo (eds.) The Discursive Politics of Gender Equality: Stretching, Bending and Policy-Making. Abingdon and New York: Routledge.

Verloo, Mieke (ed.) (2007) Multiple Meanings of Gender Equality: A Critical Frame Analysis of Gender Policies in Europe. Budapest: Central European University Press.

Verloo, Mieke et al. (2011) QUING Quality in Gender+ Equality Policies: Final Report. Vienna: Institute for Human Sciences (IWM). http:// www.quing.eu/files/ QUING_Final_Report_Jan\%2012.pdf (accessed 26 May 2015). 


\section{Acknowledgements}

This book has been partly funded by the QUING project (Quality in Gender+ Equality Policies, 2006-2011) financed by the European Commission, DG Research, through the Sixth Framework Research Programme, grant agreement 028545-2.

We would like to acknowledge and express our appreciation for the inspiration provided, and the collective work done by all the QUING and TARGET researchers as well as the participants of the TARGET meetings, the OPERA training pilots, online forums, and the Madrid Seminar. We would also like to thank the esteemed contributors to this book, as well Myra Marx Ferree and Mieke Verloo for the Foreword, and Ruya Leghari for copyediting and editorial assistance. 


\section{Preface}

The idea for this book started to take form over five years ago while working on the QUING project. QUING ("QUality IN Gender equality policies") was a European research project funded under the EU's Sixth Framework Programme, involving 12 European project partners. Led by Mieke Verloo, it placed under scrutiny gender equality policies across the EU and Turkey and encompassed five different streams. One of these, OPERA, ${ }^{1}$ consisted of the integration of knowledge on gender, intersectionality, and European gender equality policies into operational standards for gender+ training, including the training of trainers. Thus, one of the QUING/OPERA objectives was to formulate policy recommendations and standards for gender training as a way to comply with gender mainstreaming. Hence, "Gender+ training" was consequently understood as part of a gender mainstreaming strategy, and duly taken to mean training planned, organized, and/or commissioned by public institutions, and targeted at public staff and professionals.

However, early on in the project, we realized that the subjects of gender training, in particular, and of knowledge transfer through gender expertise and training, in general, were substantially under-researched. Secondly, the complexity of the subject matter and practices we encountered persuaded us to take a much broader view, coming to include other actors, such as NGOs, universities, and international development practitioners. To this end, we benefited from the TARGET project ("Transatlantic Applied Research on Gender Equity Training"), which allowed us to work jointly with North American partners, including Myra Marx Ferree (University of Wisconsin-Madison) and Kathrin Zippel (Northeastern University, Boston).

As part of this cooperation, four inspiring seminars were organized in 2008 and 2009. In May 2008 in Berlin, at the invitation of Susanne Bauer (Humboldt University), we tackled issues pertaining to the content of gender+ training, including intersectionality, the theoretical understanding of learning organization, the political dimensions of gender training, equality legislation, quality assessment, and knowledge from feminist movements. In November of that year, Mieke Verloo's team at Radboud University Nijmegen, the Netherlands, organized the second TARGET expert meeting. The gathering focused on gender training methodologies, bringing together experts and commissioners, to jointly identify which type of training would be most useful for the latter's needs. In March 2009, a seminar was held at Northeastern University, Boston, MA, on the global dimensions of gender+ training. Finally, in Madrid in June 2009, led by Emanuela Lombardo and María Bustelo of Complutense University, we engaged with gender training curricula, practices, and standards. 
Through the OPERA project, we quickly came to appreciate the richness and diversity of gender training experiences in Europe, even though these were neither systematic nor regularly organized. Focusing on the discernable gaps, problems, weaknesses, and strengths of gender training, and identifying characteristics which would feature in an "ideal" gender+ training initiative, we produced guidelines that could be useful across the board. For example, having identified several existing manuals for trainers, mostly in the international development sector, we produced a set of "guidelines" for gender training commissioners. These included explanations of the concept, content, and methodology of gender+ training, as well as practical information about the design of gender+ training initiatives, such as recommendations concerning group composition, quality control. So too did these entail recommendations on how to address resistances, alongside tools for the evaluation and monitoring of gender+ training.

In addition to the aforementioned meetings, jointly held with the TARGET project, several other valuable research activities were carried out under the QUING/OPERA initiative and have served to inspire this book. Especially worth mentioning are a survey on existing gender training practices in Europe; a database on gender trainers, which was transferred to the European Institute for Gender Equality (EIGE) upon completion of the QUING project in 2011; and numerous activities for training trainers. Moreover, gender+ training pilots of selected "best practices" were undertaken, which we felt should be embedded within broader gender equality strategies. This was done in order to contribute to the theoretical development of gender and feminist knowledge transfer, particularly in light of our conviction that inductive "learning from practice" was sorely needed.

Finally, we learnt that effective "training the trainers" activities should emphasize the need for trainers to be self-reflective about their own practices and that networking with the community of active gender trainers helps to foster such self-reflexivity. With the model of Communities of Practice in mind, three online forums were organized. These concerned how to integrate intersectionality and gender/feminist theory; how to use truly participatory and experiential methodology; and how to deal with resistances to gender+ training. Thereafter, a final face-to-face conference was also held.

This final conference was a key international one held at Madrid's Complutense University, on the 3rd and 4th of February, 2011, with the overarching theme "Advancing Gender+ Training in Theory and Practice". The event brought together academics, practitioners, policymakers, and commissioners to explore key issues in gender+ training. Topics discussed included ensuring quality in gender+ training - encompassing the definition of curriculum standards, the monitoring and evaluation of training activities, and the definition of quality criteria - and developing practice through reflexivity, involving the communication of feminist and gender 
studies theory in training, participatory-experiential methodologies, and mainstreaming intersectionality. Debates also revolved around strengthening gender + training through a Community of Practice and addressing how best to address resistances and negotiate with commissioners, as well as the professionalization of gender + training activities.

At the conference, the Madrid Declaration on Advancing Gender+ Training in Theory and Practice (see the Appendix to this book) was developed. This Declaration aims at producing a mission statement wherein gender+ training is based on feminist and gender theories translated into practice, and combines competence and capacity building with knowledge transfer. It also seeks to confront attitudes which could hinder the application of said knowledge and competences.

Thus, the challenge had begun. The principles outlined in the Madrid Declaration have served as a step forward in the professionalization of gender+ training in several countries, contributing to the global discussion on feminist knowledge transfer and supporting the development of a general framework for conducting gender + training as part of broader gender mainstreaming strategies. At the individual level, this has enriched the editors of this book in terms of their own reflections and practice as researchers, policy advisors and evaluators, and gender trainers. These have been developed in contexts as different as those of the European Evaluation Society, chaired by María Bustelo in 2012-2013, the online community of practice launched by the UN Women Training Centre on gender+ training and moderated by Lucy Ferguson, or the development of gender training strategies in research and academia as part of the EU-funded EGERA project (FP7, 2014-2017) for Maxime Forest.

But, it is clear that in-depth discussion of many of the issues raised during the QUING/OPERA project is still very much needed. So too is a theoretical contribution regarding processes of feminist knowledge transfer through gender + training and gender expertise. We hope this book will go some way towards filling this gap.

María Bustelo, Lucy Ferguson, and Maxime Forest May 2015

\section{Notes}

1. In addition to the OPERA project, the other five sub-programmes of the QUING initiative were: (1) LARG, which consisted of a comparative analysis of the differences, similarities, and inconsistencies in the field of gender+ equality between the EU and its Member States, as well as developing a methodology that combined Frame and Voice; (2) WHY, which aimed at explaining those similarities, differences, and inconsistencies in gender+ equality policies across Europe, paying specific attention to differences in civil society interfaces; (3) STRIQ, a study of how intersectionality is dealt within gender+ equality policies across the EU and 
its Member States, including the study of intersectional bias; and (4) FRAGEN, the construction of a database of gender+ equality frames that originate in feminist movements across Europe, leading to an open database.

2. "Gender + " is taken to denote the intersections between gender and other inequality grounds. 


\section{Contributors}

Viviane Albenga is a French sociologist who specializes in the sociology of gender in the spheres of cultural practices and educational policies. Her PhD, attained in 2009 at the Ecole des Hautes Etudes en Sciences Sociales (Paris), advocates a gender approach for reading practices, and she won the Prize for Gender Studies PhD of the city of Paris in 2010. She has published several papers in peer-reviewed journals, as well as a number of books regarding gender and reading; gender and musical practices; and policies addressing the issue of gender-based violence in schools. She has recently co-edited a special issue for the French journal Politix (2015/1, Number 109) on ordinary appropriations of feminist ideas. She is also a member of the French team of EGERA (Effective Gender Equality in Research and the Academia) at Paris' Sciences Po-OFCE and takes part in the PRESAGE project, the gender studies programme concerning teaching and research at Sciences Po.

María Bustelo is Associate Professor of Political Science and Public Administration at Madrid's Complutense University (UCM), teaching on evaluation, public policies, and gender and politics. She is Director of UCM's Master's degree on the Evaluation of Programmes and Public Policies, and a member of UN Women's Global Evaluation Committee (2014-2016) and the UN Women Training Centre's Expert Group on Gender Training. She has been President of the European Evaluation Society (2012-2013), a member of the Board of Directors Committee of the Spanish National Agency for the Evaluation of Public Policies (2007-2011), and leader of several national and European research projects at UCM on the quality of gender equality policies, such as MAGEEQ (FP5) and QUING (FP6). She and her team act as project evaluator for GENOVATE ("Transforming Organisational Culture for Gender Equality in Research and Innovation") (2013-2016) under FP7. She has published widely on evaluation theory and methodology, and gender equality policies, including intersectionality, gender mainstreaming evaluation, and policy frame analysis. Her latest publications include "Three Decades of State Feminism and Gender Equality Policies in Multi-Governed Spain" in Sex Roles and a contribution to Revista de Investigaciones Feministas' special issue on public policies in 2015.

Anne-Charlott Callerstig is a researcher at Örebro University, Sweden, in political science (public policy and administration) and gender studies. She has extensive experience in both research and practical work surrounding equality issues in public sector organizations, including the Swedish Equality Ombudsman. She is currently involved in a research project studying the 
implementation of national gender equality objectives and gender mainstreaming in local municipalities. She is also an expert in national investigation on Sweden's gender equality policy and organization, launched by the government in 2014. Her research interests include equality policies and organizations; policy implementation and evaluation; public administration; labour market politics; European equality politics; and interactive research approaches. Her doctoral thesis, "Making equality work: Ambiguities, conflicts and change agents in the implementation of equality policies in public sector organisations", was published in 2014 at Linköping University, Sweden.

Tine Davids is a lecturer and researcher at the Department of Anthropology and Development Studies, as well as the Centre for International Development Issues (CIDIN), at Radboud University Nijmegen, the Netherlands. She is involved in teaching and research on gender, politics, globalization, and (return) migration. She has published internationally on these themes, including in such prestigious journals as the European Journal of Women's Studies, New Diversities, and Third World Quarterly. She was also coeditor of a special issue of the Women Studies International Forum, "Embodied Engagements: Feminist ethnography at the crossing of knowledge production and representation" (2014), as well as the books Women, Gender and Remittances (2015) and The Gender Question in Globalization (2005/2007). She further participated in the "On Track with Gender" initiative, in which CIDIN, the Dutch Ministry of Foreign Affairs, Hivos, Oxfam Novib, ICCO, Cordaid, and the Royal Tropical Institute (KIT) engaged in a process of reflection on the policy, practice, and theory of gender mainstreaming. One of the results in this process, amongst others, was a special issue for the Journal of International Development (2014), which she co-edited with Anouka van Eerdewijk.

Lucy Ferguson explicitly combines the roles of academic, consultant, and practitioner. As a researcher, she is associated with the Unidad de Género, Instituto de Estudios Internacionales, of Madrid's Complutense University. Her research on working as a gender expert has been published in the International Feminist Journal of Politics. She was also a member of the QUING/OPERA research team. As a consultant, she works for the UN Women Training Centre, moderating the Community of Practice and producing content on Training for Gender Equality, for example a recent review of gender training since the Beijing Conference. She has coordinated Virtual Dialogues on topics such as transformation, resistances, and online learning. As a practitioner, she has worked as a gender expert and trainer in her specialist field of tourism, on which she has published widely in academic journals. From 2010 to 2012, she was a gender advisor to the United Nations World Tourism Organization, developing projects and providing policy advice. She 
is a founding director of Equality in Tourism, an organization which promotes gender equality in the sector and has provided gender training to several tourism companies. In combining these three roles, her work offers a reflection on the politics of feminist knowledge transfer that is strongly grounded in both theoretical and practical feminist knowledges.

Maxime Forest is a senior researcher and lecturer at Sciences Po Paris (OFCE, CEVIPOF), and scientific supervisor of the EU-funded EGERA project (Effective Gender Equality in Research and the Academia, FP7, 2014-2017). From 2008 to 2011, he was a post-doctoral fellow at Madrid's University Complutense, under the QUING project (EU FP6). He has taught at political studies institutes in Strasbourg (2007-2008) and Toulouse (2009-2010) and been a lecturer at Paris Sorbonne University (2010-2015). His research interests include the Europeanization of gender and other equality policies; the gendered dimensions of political and social change in Eastern and Southern Europe; women in parliamentary politics and executive power; and the politics of intersectionality. He has published in Comparative European Politics, Perspectives on European Politics and Societies, Revue Internationale de Politique Comparée, and Politique Européenne. He also co-edited The Europeanization of Gender Equality Policies: A Discursive-Sociological Approach (2012) with Emanuela Lombardo. Appointed an executive member of the French High Gender Equality Council in 2013, he chairs its International and EU Affairs Committee. He regularly provides expertise to the European Institute for Gender Equality, the French Ministry for Women's Rights, and the Council of Europe.

Rahel Kunz is a lecturer at the Institute of Political and International Studies, University of Lausanne. Her main research interests are feminist international relations; and feminist, poststructuralist, and postcolonial theories. She has published in the Journal of International Political Sociology, Journal of European Integration, Migration Studies, Review of International Political Economy, and Third World Quarterly. She is also the author of The Political Economy of Global Remittances: Gender, Governmentality and Neoliberalism (2011) and co-editor of Multilayered Migration Governance: The Promise of Partnership (2011). She is currently involved in a collaborative research project on gender experts and gender expertise.

Emanuela Lombardo holds a PhD in Politics from the University of Reading, UK. She is a lecturer at the Department of Political Science and Administration II of Madrid's Complutense University, Spain. Her research concerns gender equality policies and their intersections with other inequalities, particularly in the European Union and Spain; gender mainstreaming; gender training; Europeanization; and political representation from a gender perspective. On these issues, she has published articles in peer-reviewed 
journals, such as Comparative European Politics, Political Science, Social Politics, European Integration online Papers, Journal of Women Politics and Policy, Women's Studies International Forum, International Feminist Journal of Politics, European Journal of Women's Studies, Feminist Review, Nordic Journal of Women's Studies, and Citizenship Studies, as well as chapters in edited volumes. Her latest book, co-authored with Petra Meier, is The Symbolic Representation of Gender. She has worked as a researcher in different European and Spanish projects, such as the European Commission's FP4, FP5, FP6, and POM programmes, two of which - QUING and TARGET - concern gender training as part of a broader gender mainstreaming strategy.

Lut Mergaert holds a PhD in Management Sciences from Radboud University Nijmegen, the Netherlands. For her dissertation, she studied gender mainstreaming implementation by the European Commission in the policy area of research. She is Research Director and member of the management team at Yellow Window, a consultancy company based in Belgium. She has been principal investigator and coordinator of three pan-European research projects on gender issues for the European Institute for Gender Equality (EIGE). One of these analysed the institutional capacity for gender mainstreaming in the European Commission, and the EU's 28 Member States, with a specific focus on research policies (2013). She was the research leader for the study Monitoring progress towards gender equality in the EU Sixth Framework Programme for Research and Development, covering the "Science and Society", and Social Sciences and Humanities fields (2004-2007). Also for the European Commission, she coordinated a project under which a gender toolkit was developed and 73 training sessions were organized throughout Europe to raise the research community's capacity for integrating gender aspects into research (2009-2012).

Daniela Moreno Alarcón specializes in tourism analysis with a gender focus in the field of responsible tourism. She is a Tourism Planning and Management Graduate (SEK International University, Chile), with a Master's in Tourism Planning and Management (University of Alicante, Spain), and a specialization in Gender Relations (IUDC - UCM). A PhD candidate of the programme "The Feminist Perspective as a Critical Theory", at the Faculty of Political Science and Sociology of Madrid's Complutense University, her doctoral thesis is entitled "Tourism and Gender: An essential approach in the context of responsible and sustainable development". Over the last eight years, she has promoted gender equality through incidence programmes; social inclusion; awareness raising; education for development; international cooperation; and corporate social responsibility regarding consultancy, research, education, project cycles, and emotional intelligence. She co-authored FIAPP's Tourism and Gender Guide with Lucy Ferguson, and has supported the United Nations World Tourism Organization and the Spanish 
Forum of Responsible Tourism in integrating gender issues. She is also a codirector of Equality in Tourism, an organization which promotes women's equal share of the benefits of tourism.

Elisabeth Prügl is Professor of International Relations at the Graduate Institute of International and Development Studies in Geneva, where she directs the Programme on Gender and Global Change. From 2010 to 2014, she served as Deputy Director of the Institute. She previously taught at Florida International University in Miami. Her research focuses on gender politics in international governance, in particular in the areas of agriculture, development, and conflict. She currently directs research projects on gender experts and gender expertise, gender and armed conflict, and gender and land commercialization. Recent publications include "Neoliberalising Feminism", New Political Economy (online) (September 2014), "Equality Means Business", International Political Economy, Vol. 22, 6, with Jacqui True, and Feminist Strategies in International Governance, with Gülay Caglar and Susanne Zwingel (2013). She is spending the 2014-2015 academic year as a fellow at the Women and Public Policy Program of the Harvard Kennedy School.

Anouka van Eerdewijk is a senior advisor at the Royal Tropical Institute (KIT, Amsterdam) and an affiliated researcher at the Institute for Gender Studies, Radboud University Nijmegen. Her work concerns gender mainstreaming and transformational change; norm diffusion processes and transnational dynamics; gender, sexuality, and rights; and gender in agricultural research. Her PhD thesis, "The ABC of Unsafe Sex: Gendered Sexualities in Dakar (Senegal)", brought together development studies, anthropology, and gender and sexuality studies. Her engagement with feminist knowledge transfer stems from both academic research and writing, and her work as an advisor at the interface between theory and practice. She coordinated the On Track with Gender trajectory on gender mainstreaming with Dutch development NGOs and the Ministry of Foreign Affairs. More recently, she worked with international research institutes and development agencies on capacity building, applied research, organizational learning, and policy advice to support the institutionalization of gender equality. She also coedited a special issue of the Journal of International Development on gender mainstreaming with Tine Davids; published in Globalizations and Gender and Development; and co-published an edited volume Gender Equality Norms in Regional Governance. 